\title{
The Hunt In Arabic Poetry: From Heroic to Lyric to Metapoetic
}

\author{
Jaroslav Stetkevych \\ Notre Dame, IN: University of Notre Dame Press, 2016. 356 pages.
}

In his book, The Hunt in Arabic Poetry: from Heroic to Lyric to Metapoet$i c$, Jaroslav Stetkevych traces the evolution of Arabic hunt poetry from its origins as an integral part of the heroic ode (qașīda) to becoming a genre by itself (tardiyya) during the Islamic era, and then evolving into a metapoetic self-conscious expression of poets in our modern time. The book is a collection of a revised book chapter and a number of revised articles that Stetkevych published between 1996 and 2013 discussing Arabic hunt poetry at different periods spanning from the pre-Islamic age, known in Arabic as "al-Aṣr al-jāhiliyya" (Age of Ignorance), to the contemporary era. This does not diminish the coherence of the book nor detract from Stetkevych's 
welcomed thematic approach and his contribution to literary criticism on Arabic poetry and the socio-political and linguistic factors that influenced its development and evolution.

Stetkevych divides his 256-page book into three parts. The first part, entitled "The Heroic and the Anti-Heroic in the Early Arabic Ode: The Qașīdah," consists of three chapters and discusses the evolution of the qașida (ode) during the Age of Ignorance. Stetkevych dissects the structure of the ode and shows how hunt poetry was an integral part of it (not an independent genre). In doing so, Stetkevych draws a vivid picture of the life and geosocial terrain of the period spanning from pre-Islamic to the mid-Umayyad eras.

In the first chapter, "The Hunt in the Pre-Islamic Ode", Stetkevych uses examples mainly from the Mu'allaqāt of Rabīah ibn Maqrum, Labād Ibn Rabī'ah, and the famous Imru' al-Qays to illustrate the different roles hunt poetry played based on where it fell in the structure of the ode. He further establishes that the hunt section of the ode served as the origin for what later became a genre in its own right, known as tardiyya. In the second and third chapters, "The Hunt in the Ode at the Close of the Archaic Period" and "Sacrifice and Redemption: The Transformation of Archaic Theme in al-Hutay'ah", Stetkevych distinguishes between the different terms for "hunt" and the tard that would be the "chivalrous hunt" that takes place from the back of a horse. Parsing these distinctions with poems from 'Abdah Ibn al-Ṭabīb, al-Shamardal, and 'Amr Ibn Qamìah, among others, the author sketches how hunt poetry began taking its own shape as a freestanding genre during the Umayyad period: when hunt poetry "is no longer explicitly 'chivalrous'... we are now in the realm of falconry" (55).

The second part of the book, "The Hunt Poem as Lyric Genre in Classical Arabic Poetry: The Tardiyyah", is made up of four chapters that discuss the maturation of the hunt poem under 'Abbasid rule. During that period, the cultural, economic, scientific, and social renaissance left its impact on poets and poetry. Hunt poetry became a genre of its own, taking an independent form made of hunt-specialized shorter lyrics. Stetkevych begins this section in chapter 4, "The Discreet Pleasures of the Courtly Hunt: Abū Nuwās and the 'Abbasid Tardiyyah". He shows how the move of hunt poetry from subjective to objective description was utterly distinctive under "Abu Nuwas, the master of archaic formulas, who is capable of employing those formulas in conceits that are no longer archaic" (102). Chapter 5, "From Description to Imagism: 'Alī Ibn al-Jahm's 'We Walked over Saffron Meadows," shows how Ibn al-Jahm and other Abbasid poets such as Ibn al- 
Mu'tazz and Abū Firās al-Ḥamdānī "exercise considerable stylistic freedom in developing their own markedly varied but distinctive tardiyyah-poems from the broadly imagist to the highly lyrical to the fully narrative" (131). Stetkevych shows how the rhythm of hunt poetry was liberated as the Abbasid poets moved from the rajaz meter used in pre-Islamic hunt poetry to modifying and modulating "the tawil meter to create the unique rhythmic qualities" (131). In chapter 6, "Breakthrough into Lyricism: The Tardiyyahs of Ibn al-Mu'tazz," the author uses multiple examples to show how "the tardiyyah not only found that new lyrical voice but also allowed it ... to become a closely integrated and even more broadly formative part of that poet's multi-genre 'project' of a 'new lyricism' of Arabic poetry" (183). Chapter 7, "From Lyric to Narrative: The Tardiyyah of Abu Firas al-Hamdanī," demonstrates how the prince poet "abandons the short lyric monorhyme for the sprawling narrative rhymed couplets (urjuzah muzdawijah)" (9). Stetkevych notes that although this "shift did not result (yet) in the achievement of a separate narrative genre, it can ...be rightfully viewed as a step in the exploration of the possibility of a large narrative form" (187).

The third and final section, "Modernism and Metapoesis: the Pursuit of the Poem," discusses the revival of hunt poetry by modernist poets after being neglected for centuries. Chapter 8, "The Modernist Hunt Poem in 'Abd al-Wahhab al Bayatī and Ahmad 'Abd al Mu'țī Hijazī," examines two poems of the two poets, both entitled Tardiyyah. Stetkevych argues that the Iraqi free-verse poet, al-Bayatī, transformed the "genre-and form-bound, rhymed and metered lyric... into a formally free exploration of the dramatic and tragic image of the hunted hare as a metaphor for the political and cultural predicament of modern man" (9). Meanwhile, Hijazi’s Tardiyyah transforms "the poignant lyricism of the traditional hunt poem into an expression of the poet's personal experience of political exile and poetic restlessness and frustration" (10). The author concludes that the two poets' explorations into tardiyyah "helped not only to preserve and activate the classical metaphor of hunt/tardiyyah into modernity, but in equal measure to validate and enrich the achievements of modern Arabic poetry" (242). In the last chapter, "The Metapoetic Hunt of Muhammad 'Afîfi Mațar," Stetkevych - through interpretation, comparison, and criticism-shows how Matar's modern poetry while "hermeneutically connected to the old genre... [is] very personal mythopoesis" (10).

Stetkevych's book does not discuss Andalusian hunt poetry, such as that of 'Abbās Ibn Firnās, Ibn Hadhyal and Ibn al-Khațīb, nor the Tardi- 
yyah of the contemporary Egyptian poet 'Abdulrahman Youssef, published in 2011 after the revolution in Tunisia and two days before the Egyptian revolution started. While including such examples would have further bolstered this already strong and convincing argument and further illustrated the evolution of hunt poetry from the pre-Islamic era into modern times, their absence does not take away from the book writ large. Stetkevych's excellent English translations of the poetry cited make his examples more accessible to readers who do not know Arabic. Overall, the book is a very valuable addition to literary criticism of Arabic poetry written in English and will surely be a great asset for scholars, students, and others interested in Arabic poetry as a reflection of a cultural and humanistic experience.

Gaby Semaan Assistant Professor of Arabic University of Toledo 